\title{
Korelasi Latar Belakang Pendidikan dan Minat Belajar Bahasa Arab dengan Masa Studi Mahasiswa Prodi Pendidikan Bahasa Arab Fakultas Ilmu Tarbiyah dan Keguruan UIN Raden Fatah Palembang
}

\author{
Yuniar $^{1}$, Mursyidah ${ }^{2}$, \\ ${ }^{1}$ Universitas Islam Negeri Raden Fatah Palembang \\ 2 Universitas Islam Negeri Raden Fatah Palembang \\ E-mail: yuniar uin@radenfatah.ac.id
}

\begin{abstract}
The ideal lecture is to be able to study in a study program that is an option according to your interests and can be completed on time. The PBA Study Program with relatively diverse input dynamics has an impact on the lack of students who can finish at the ideal time. For this reason, in this study, it will be seen whether there is a correlation between the three variables above. $X 1, X 2$ and $Y$. The results of the calculations are: 1) there is a positive and significant correlation between educational background (X1) and the study period of PBA Study Program students (Y). This is indicated by the calculated $r$ value (Person Correlation) of $0.400>r$ table of 0.244 and a sig. 2 tailed value of $0.001<0.05$.2) there is a positive and significant correlation between interest in learning (X2) and $Y$. This is evidenced by the calculated $r$ value of $0.520>r$ table 0.244 , and the sig. 2 tailed value of $0.000<0.05$. 3) There is a positive and significant correlation between X1 and X2 together on Y. This is based on multiple correlation analysis with the result or $R$ value of 0.525 and the probability value (sig. $F$ change) $=0.000$. Because the sig. $F$ canghe value is $0,000<0.05$, this indicates a significant relationship. So the conclusion to the three answers to the hypothesis above is that all Ho are rejected and Ha are accepted.
\end{abstract}

Keywords: Correlation, Educational Background, Study Interest and Study Period

\begin{abstract}
Abstrak
Perkuliahan yang ideal adalah bisa belajar di prodi yang menjadi pilihan sesuai minat serta bisa selesai tepat waktu. Prodi PBA dengan dinamika input yang relatif beragam berimbas kepada minimnya mahasiswa yang bisa selesai di waktu ideal. Untuk itu dalam penelitian ini, akan dilihat adakah korelasi antara tiga variabel di atas. X1, X2 dan Y. Hasil penghitunganya adalah: 1) adanya korelasi yang positif dan signifikan antara latar belakang pendidikan (X1) dengan masa studi mahasiswa Prodi PBA (Y). Hal ini dibutikan dengan nilai $r$ hitung (Person Correlation) sebesar 0,400 > $r$ tabel 0,244 dan nilai sig.2 tailed ebesar $0,001<0,05.2$ ) adanya korelasi yang positif dan signifikan antara minat belajar (X2) dengan Y. Hal ini dibutikan dengan nilai $r$ hitung sebesar 0,520 > r tabel 0,244, dan nilai sig. 2 tailed sebesar $0,000<0,05$. 3) Ada korelasi yang positif dan signifikan antara X1 dan X2 secara bersama-sama terhadap Y. Hal ini berdasarkan analisis korelasi berganda dengan hasil atau nilai R sebesar 0,525 dan nilai probabilitas (sig. $\mathrm{F}$ change) $=0,000$. Karena nilai sig.F canghe $0,000<0,05$, menunjukan adanya hubungan yang signifikan. Maka kesimpulan terhadap tiga jawaban hipotesa di atas adalah semua Ho ditolak dan Ha diterima.
\end{abstract}

Kata Kunci: Korelasi, Latar Belakang Pendidikan, Minat Belajar dan Masa Studi 
Korelasi Latar Belakang Pendidikan Dan Minat Belajar Bahasa Arab Dengan Masa Studi Mahasiswa Prodi Pendidikan Bahasa Arab Fakultas Ilmu Tarbiyah Dan Keguruan UIN Raden Fatah Palembang

\section{PENDAHULUAN}

Dunia kampus merupakan dunia dimana setiap mahasiswa dengan bebas memilih kehidupan yang mereka inginkan. Disinilah dituntut suatu tanggung jawab moral terhadap diri masing-masing sebagai individu untuk dapat menjalankan kehidupan yang bertanggung jawab dan sesuai dengan moral yang hidup dalam masyarakat. Selain itu mahasiswa memiiliki tanggung jawab sosial yaitu bahwa keberadaan dan segala perbuatannya tidak hanya bermanfaat untuk dirinya sendiri tetapi juga membawa manfaat bagi lingkungan sekitarnya. Bahkan tidak hanya itu, tanggung jawab intelektual harus juga dilakukannya yakni mahasiswa sebagai insan intelektual harus dapat mewujudkan status tersebut dalam ranah kehidupan nyata.

Pada hakekatnya mahasiswa melanjutkan pendidikan di Perguruan Tinggi dengan harapan agar bisa mengikuti pendidikan dengan baik. Tetapi ternyata tidak selamanya demikian. Ada berbagai masalah yang mereka hadapi berkaitan dengan proses studi mahasiswa di Perguruan Tinggi yang mana permasalahan tersebut sudah barang tentu menghambat prestasi akademiknya bahkan kepada penyelesaian studi mereka dalam memperoleh gelar kesarjanaan.

Sebagaimana aturan yang umum berlaku di perguruan tinggi adalah bahwa beban studi mahasiswa yang harus ditempuh untuk level sarjana adalah berkisar 144-148 SKS dengan masa studi rata-rata 4 tahun sampai 7 tahun. (Permenristekdikti Nomor 44, 2015) Dilihat dari aturan yang diterapkan tersebut untuk masing-masing program studi idealnya menyiapkan mahasiswanya untuk dapat menyelesaikan studi dengan tepat waktu. Tetapi realitas di lapangan masih ada mahasiswa yang terkena Drop Out (DO) ataupun masih banyak nya mahasiswa yang masa studinya di atas 5 tahun.

Keberhasilan mendapatkan prestasi salah satunya sangat dipengaruhi oleh minat dan motivasi yang tinggi dalam belajar. Karena hal itulah yang akan menggerakkan tingkah laku untuk belajar. Minat adalah kecenderungan subjek yang menetap, untuk merasa tertarik pada bidang studi atau pokok bahasan tertentu dan merasa senang mempelajari materi itu.(W.S, 1996:188) Minat merupakan salah satu faktor yang dapat mempengaruhi usaha yang dilakukan seseorang. Minat yang kuat akan menimbulkan usaha yang gigih, serius, dan tidak mudah putus asa dalam menghadapi tantangan. 
Korelasi Latar Belakang Pendidikan Dan Minat Belajar Bahasa Arab Dengan Masa Studi Mahasiswa Prodi Pendidikan Bahasa Arab Fakultas Ilmu Tarbiyah Dan Keguruan Uin Raden Fatah Palembang

Beberapa unsur di atas apabila dikaitkan dengan program studi maka dapat disimpulkan bahwa individu yang berminat terhadap Prodi Pendidikan Bahasa Arab akan mempunyai ketertarikan kuat yang diteruskan dengan pemusatan pengetahuan dan informasi, perasaan senang yang kemudian mendorong individu tersebut untuk mewujudkan kehendaknya yakni sukses belajar di prodi Pendidikan Bahasa Arab dalam waktu yang ideal.

Namun kenyataan yang ada di prodi Pendidikan Bahasa Arab Fakultas Ilmu Tarbiyah dan Keguruan UIN Raden Fatah Palembang tidaklah demikian. Prodi yang dapat dikatakan cukup "langka peminat" ini juga ternyata sulit mengeluarkan alumni tepat waktu. Dari dokumentasi lima tahun terakhir yang peneliti telusuri adalah bahwa persentase mahasiswa prodi PBA yang lulus tepat waktu yaitu selesai paling lama 4 tahun dapat dilihat pada tabel berikut:

Tabel 1.

Data Persentase Kelulusan Alumni PBA

\begin{tabular}{|c|c|c|c|c|}
\hline No. & Tahun Masuk & Jumlah Mhs & $\begin{array}{c}\text { Jumlah Mhs } \\
\text { Yang lulus } \\
\text { Tepat Waktu }\end{array}$ & Dalam \% \\
\hline 1 & 2011 & 50 & 18 & $36,00 \%$ \\
\hline 2 & 2012 & 99 & 28 & $28,28 \%$ \\
\hline 3 & 2013 & 93 & 17 & $18,28 \%$ \\
\hline 4 & 2014 & 65 & 31 & $47,7 \%$ \\
\hline 5 & 2015 & 112 & 20 & $18,75 \%$ \\
\hline
\end{tabular}

Sumber: Dokumentasi Prodi, 2020

Idealnya mahasiswa memilih prodi yang memang diminatinya. Sehingga ada kepuasan tersendiri saat menjalankannya. Seseorang akan merasa nyaman ketika melakukan sesuatu tanpa tekanan dan sesuai dengan minat mereka. Jika seseorang melakukannya dengan perasaan senang , kemungkinan akan berhasil tentunya akan besar pula dan ini juga dimungkinkan berimbas kepada masa studi mereka. Namun jika seseorang melakukan suatu pekerjaan dengan paksaan atau dibawah tekanan maka yang akan terjadi adalah rasa tidak nyaman dan seringkali mengakibatkan kegagalan.

Untuk itu dalam penelitian ini, peneliti akan melihat adakah korelasi atau hubungan antara beberapa variabel di atas. Yaitu, latar belakang pendidikan mahasiswa sebelumnya dan minat belajar bahasa Arab mahasiswa prodi Pendidikan Bahasa Arab dengan keberhasilan mereka belajar di perguruan tinggi yang ditandai dengan cepatnya masa studi mereka di prodi tersebut. 
Korelasi Latar Belakang Pendidikan Dan Minat Belajar Bahasa Arab Dengan Masa Studi Mahasiswa Prodi Pendidikan Bahasa Arab Fakultas Ilmu Tarbiyah Dan Keguruan UIN Raden Fatah Palembang

\section{TEORI}

Dalam penelitian ini akan dilihat teori untuk tiga variabel yaitu latar belakang pendidikan yang dapat dilihat pada dua sisi, yaitu kesesuaian antara bidang ilmu yang ditempuh dengan bidang pekerjaan/tugas dan jenjang pendidikan.(Wahdanfari, 2014:33) Untuk minat, peneliti merujuk pada Slameto, dimana minat adalah suatu rasa lebih suka rasa ketertarikan pada suatu benda atau aktivitas tanpa ada yang menyuruh.(Slameto, 2003:180)

Minat belajar adalah aspek psikologi seseorang yang menampakkan diri dalam beberapa gejala, seperti: gairah, keinginan, perasaan suka untuk melakukan proses perubahan tingkah laku melalui berbagai kegiatan yang meliputi mencari pengetahuan dan pengalaman, dengan kata lain minat belajar itu adalah perhatian, rasa suka, ketertarikan seseorang (siswa) terhadap belajar yang ditunjukkan melalui keantusiasan, partisipasi dan keaktifan dalam belajar.

Menurut Safari ada beberapa indikator siswa yang memiliki minat belajar yang tinggi. Hal ini dapat dikenali melalui proses belajar di kelas maupun di rumah, yaitu: (Safari, 2003:60) (1) Perasaan Senang. Seorang siswa yang memiliki perasaan senang atau suka terhadap mata pelajaran yang dipelajari, maka ia harus terus mempelajari ilmu yang berhubungan dengan mata pelajaran tersebut. Sama sekali tidak ada perasaan terpaksa untuk mempelajari bidang tersebut. (2) Ketertarikan Siswa. Berhubungan dengan daya gerak yang mendorong siswa untuk cenderung merasa tertarik pada orang, benda, kegiatan, atau bisa berupa pengalaman efektif yang dirasakan oleh kegiatan itu sendiri. (3) Perhatian dalam Belajar. Adanya perhatian juga menjadi salah satu indikator minat. Perhatian merupakan konsentrasi atau aktifitas jiwa kita terhadap pengamatan, pengertian, dan sebagainya dengan mengesampingkan hal yan lain. Seorang yang memiliki minat pada objek tertentu maka dengan sendirinya dia akan memperhatikan objek tersebut. Misalnya, seorang siswa menaruh minat terhadap pelajaran IPA, maka ia berusaha untuk memperhatikan penjelasan dari gurunya.(Slameto, 2003:58) (4) Keterlibatan Siswa, (5) Ketertarikan seseorang akan sesuatu objek yang mengakibatkan orang tersebut senang dan tertarik untuk melakukan atau mengerjakan kegiatan dari objek tersebut.(Safari, 2003:60) (6) Intensitas Belajar Siswa. Berminat tidaknya seseorang terhadap suatu aktivitas dapat dilihat dari keaktifannya dalam bidang tertentu. Suatu contoh misalnya, seseorang yang 
Korelasi Latar Belakang Pendidikan Dan Minat Belajar Bahasa Arab Dengan Masa Studi Mahasiswa Prodi Pendidikan Bahasa Arab Fakultas Ilmu Tarbiyah Dan Keguruan Uin Raden Fatah Palembang

berminat dalam mempelajari suatu mata pelajaran dia akan aktif dalam fisik maupun psikis. Hal ini sesuai dengan yang diungkapkan oleh Sardima bahwa ketekunan merupakan salah satu ciri minat dalam diri sesorang.(Sardiman, 1994)

Masa studi adalah waktu yang dibutuhkan seseorang menempuh suatu program studi pada tingkat strata tertentu yang dihitung melalui Satuan Kredit Semester minimal, artinya masa studi seseorang dikatakan berakhir apabila telah memenuhi beban belajar yang ditentukan masing-masing lembaga pendidikan dan telah menyelesaikan tugas akhir. Dalam beberapa hasil penelitian terbukti banyak yang mempengaruhi masa studi mahasiswa di antaranya adalah minat belajar dan kemampuan akademik.

\section{METODE}

Pendekatan yang digunakan dalam penelitian ini adalah pendekatan kuantitatif dengan metode survey. Populasi adalah mahasiswa PBA yang berjumlah 465 orang dan sampel berjumlah 65 orang yang ditentukan dengan purposif sampling. Data diambil melalui angket yang kemudian dianalisis statistik dengan bantuan aplikasi SPSS 16.0. proses penganalisisan yang dilakukan adalah (1) uji kelayakan instrumen dengan menguji validitas dan reabilitas,(2) Uji Asumsi Klasik yaitu uji normalitas dan linearitas, (3) Uji hipotesis yaitu dengan uji korelasi product momen dan korelasi ganda dilanjutkan dengan (4) uji prediksi yaitu regresi sederhana dan regresi ganda.

\section{HASIL DAN PEMBAHASAN}

Dari hasil angket yang disebar kepada responden, peneliti untuk variabel latar belakang pendidikan memperoleh data bahwa mahasiswa PBA angkatan 2014 berasal dari berbagai jenis lembaga pendidikan yang tersebar di Indonesia yaitu pesantren (dengan sistem asrama maupun kalong) madrasah, sekolah Islam dan sekolah umum. Namun secara rinci yang mendominasi adalah 36\% mahasiswa PBA angkatan 2014 berasal dari pesantren dengan sistem asrama dan 30\% dari sekolah umum (SMU/SMK). Selain itu dalam hitungan persentase yang relatif kecil mereka juga ada yang berasal dari Madrasah Aliyah, pesantren dengan sistem kalong dan Sekolah Islam. 
Korelasi Latar Belakang Pendidikan Dan Minat Belajar Bahasa Arab Dengan Masa Studi Mahasiswa Prodi Pendidikan Bahasa Arab Fakultas Ilmu Tarbiyah Dan Keguruan UIN Raden Fatah Palembang

Secara jelas dapat dilihat pada diagram berikut ini

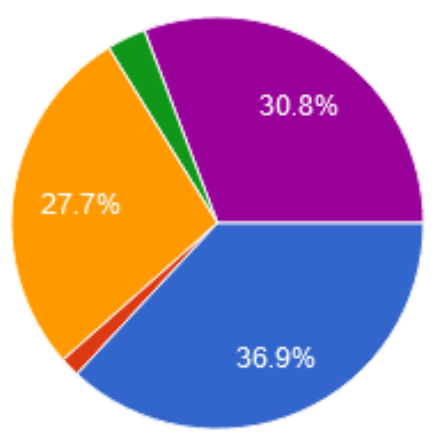

Pesantren

Pesantren dengan sistem kalong/ tanpa menginap

Madrasah Aliyah

Sekolah Islam

SMU/SMK

Untuk latar belakang dan pengalaman keilmuan yang telah diperoleh sebelumnya berdasarkan data yang diperoleh peneliti melihat bahwa sebagian besar responden belajar bahasa Arab di bangku sekolah dengan persentase 83,1\% dan dengan durasi waktu rata-rata 3-4 jam seminggu saja dan tidak diikuti dengan belajar tambahan berupa kursus. Maka 38,5\% mereka memiliki kemampuan berbahasa yang relatif minim yaitu hanya menguasai satu keterampilan berbahasa saja.

Berikut dapat dilihat penjelasan dalam bentuk diagram di bawah ini

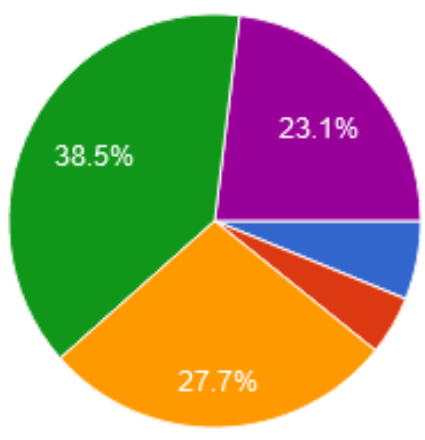

Menguasai 4 keterampilan berbahasa

Menguasai 3 keterampilan berbahasa

Menguasai 2 keterampilan berbahasa

Menguasai 1 keterampilan berbahasa

Tidak menguasai satupun

keterampilan berbahasa

Untuk melihat minat belajar, peneliti mendistribusikan angket yang berisi empat indikator dalam bentuk skala likert, yaitu indikator pertama, kesenangan dalam belajar ada enam pernyataan yang diajukan, kemudian indikator kedua, ketertarikan dalam belajar juga ada enam pernyataan, indikator ketiga, perhatian dalam belajar, enam pernyataan dan keempat, keterlibatan dalam belajar diajukan dengan jumlah yang sama yaitu enam pernyataan. Jadi semuanya berjumlah 24 pernyataan untuk melihat kadar atau tingkat minat seorang mahasiswa atau responden. Hasil yang didapat adalah bahwa minat belajar bahasa Arab terkategori 
Korelasi Latar Belakang Pendidikan Dan Minat Belajar Bahasa Arab Dengan Masa Studi Mahasiswa Prodi Pendidikan Bahasa Arab Fakultas Ilmu Tarbiyah Dan Keguruan Uin Raden Fatah Palembang

baik hal ini karena dari 24 pernyataan yang disebarkan setelah dianalisis dengan skala likert persentase tertinggi pada nilai empat.

Untuk data masa studi mahasiswa, peneliti merujuk tabel di atas sehingga dapat dikelompokkan bahwa mahasiswa PBA angkatan 2014 yang menjadi responden dalam penelitian ini sebanyak 38,5 \% menyelesaikan studi di tahun 2016/2017. 33,8 \% menyelesaikan studi di tahun 2017/2018. 20\% di tahun 2018/2019 dan sampai saat ini ada yang belum selesai sebanyak 6,2\%. Dapat dilihat pada diagram berikut:
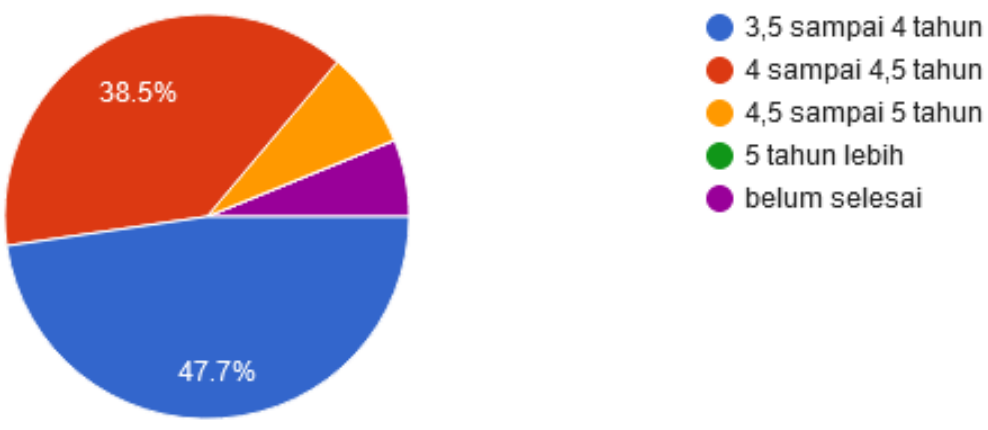

Jika dihitung lamanya masa studi maka dihitung 47,7\% responden meemiliki masa studi 3,5 sampai 4 tahun. 38,5\% lama studi mereka adalah 4 sampai 4,5 tahun dan kisaran 4,5 sampai 5 tahun adalah 7,7\% untuk yang sampai saat ini belum selesai sebanyak $6,2 \%$ berarti terhitung masa studi nya sampai saat ini adalah mencapai 6 tahun lebih.

Selanjutnya masa penyelesaian tugas akhir yang peneliti lihat sangat mempengaruhi masa studi yaitu sebanyak 50,8\% selesai dalam waktu 6 bulan, sebanyak 35,4\% kurang atau sama dengan satu tahun. Sebanyak 6,2 \% sampai saat ini masih berusaha menyelesaikan tugas akhirnya.

Untuk mata kuliah teori $60.9 \%$ mereka selesaikan dalam waktu 3 tahun dan 32,8 \% dalam waktu 3,5 tahun. Untuk responden yang pernah mengikuti semester antara/pendek sebanyak 32,3 \% dengan keterangan pernah mengulang satu mata kuliah, 15,4\% pernah mengulang pada semester antara untuk dua mata kuliah dan 47,7 \% tidak pernah mengulang mata kuliah sama sekali. Untuk responden yang Stop Out sebagai salah satu sebab panjangnya masa studi mahasiswa, $100 \%$ responden menjawab tidak pernah melakukannya selama proses perkuliahan. Berikut simpulan jawabannya dalam bentuk diagram. 


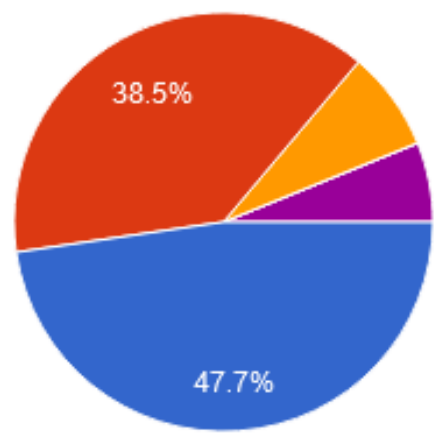

Berikut hasil analisis terhadap data ketiga variabel di atas,

1) Uji Asumsi Klasik

a. Uji Normalitas

Tabel 2.

Uji Normalitas

Latar Belakang Pendidikan, Minat Belajar, dan Masa Study

One-Sample Kolmogorov-Smirnov Test

\begin{tabular}{|c|c|c|c|c|}
\hline & & Pendidikan & Minat_Belajar & Masa_Studi \\
\hline N & & 65 & 65 & 65 \\
\hline Normal Parameters & Mean & 17.14 & 99.17 & 26.05 \\
\hline & $\begin{array}{l}\text { Std. } \\
\text { Deviation }\end{array}$ & 6.023 & 8.381 & 4.577 \\
\hline Most Extreme & Absolute & .142 & .060 & .194 \\
\hline Differences & Positive & .130 & .050 & .194 \\
\hline & Negative & -.142 & -.060 & -.174 \\
\hline Kolmogorov-Smirnov & & 1.149 & .487 & 1.563 \\
\hline Asymp. Sig. (2-tailed) & & .143 & .972 & .015 \\
\hline Test distribu & & & & \\
\hline
\end{tabular}

Pada penelitian ini, karena sampel lebih dari 50 sampel maka digunakan uji Kolmogorov-Smirnov. Dalam pengujian suatu data dikatakan berdistribusi normal apabila nilai signifikan lebih dari 0.05 (sig. > 0,05).

Dari tabel diatas dapat dilihat Nilai signifikansi (p) pada uji kolmogorov-smirnov Latar Belakang Pendidikan (X1) adalah $0.143>0.05$, sehingga berdasarkan uji normalitas kolomogorov-smirnov data berdistribusi normal. Nilai signifikansi (p) pada uji kolmogorov-smirnov Minat Belajar (X2) adalah $0.972>0.05$, sehingga berdasarkan uji normalitas kolomogorovsmirnov data berdistribusi normal. Sedangkan Nilai signifikansi (p) pada uji kolmogorov-smirnov Masa Study (Y) adalah $0.015<0.05$, sehingga berdasarkan uji normalitas kolomogorov-smirnov data berdistribusi normal. 
b. Uji Linearitas

Tabel 3.

Uji Linearitas

\begin{tabular}{|c|c|c|c|c|c|c|c|}
\hline \multicolumn{8}{|c|}{ ANOVA Table } \\
\hline & & & $\begin{array}{l}\text { Sum of } \\
\text { Squares }\end{array}$ & df & $\begin{array}{l}\text { Mean } \\
\text { Square }\end{array}$ & $\mathrm{F}$ & Sig. \\
\hline \multirow{5}{*}{$\begin{array}{l}\text { Masa_Studi } \\
\text { Pendidikan }\end{array}$} & \multirow{3}{*}{$\begin{array}{l}\text { Between } \\
\text { Groups }\end{array}$} & (Combined) & 950.662 & 19 & 50.035 & 5.770 & .000 \\
\hline & & Linearity & 214.428 & 1 & 214.428 & 24.729 & .000 \\
\hline & & $\begin{array}{l}\text { Deviation } \\
\text { from } \\
\text { Linearity }\end{array}$ & 736.234 & 18 & 40.902 & 4.717 & .000 \\
\hline & \multicolumn{2}{|c|}{ Within Groups } & 390.199 & 45 & 8.671 & & \\
\hline & \multicolumn{2}{|l|}{ Total } & 1340.862 & 64 & & & \\
\hline
\end{tabular}

Berdasarkan hasil uji linieritas pada tabel ANOVA diatas diketahui bahwa nilai Sig. Linearity sebesar 0,000<0,05, maka dapat disimpulkan bahwa antara variabel latar belakang pendidikan dan masa studi terdapat hubungan yang linear.

2) Uji Hipotesis

Tabel 4.

Uji Korelasi Secara Variabel

\begin{tabular}{|ll|r|r|r|}
\hline \multicolumn{2}{c|}{ Correlations } & \\
\hline Pendidikan & Pendidikan & Minat_Belajar & Masa_Studi \\
& Sig. (2-tailed) & 1 & $.670^{* *}$ & $.400^{* *}$ \\
& $\mathrm{~N}$ & & .000 & .001 \\
& Pearson Correlation & $.670^{* *}$ & 65 & 65 \\
\hline Minat_Belajar & Sig. (2-tailed) & .000 & 1 & $.520^{* *}$ \\
& $\mathrm{~N}$ & 65 & .000 \\
& Pearson Correlation & $.400^{* *}$ & $.520^{* *}$ & 65 \\
\hline Masa_Studi & Sig. (2-tailed) & .001 & .000 & 1 \\
& $\mathrm{~N}$ & 65 & 65 & 65 \\
\hline
\end{tabular}

Sebelum melakukan pembahasan lebih lanjut perlu diketahui beberapa hal berikut, diantaranya adalah nilai signifikansi dari output SPSS dan pengambil keputusan setelah diketahui nilai signifikansi. Jika nilai signifikansi $\leq 0,05$, maka hipotesis kerja/hipotesis alternatif diterima yang berarti ada hubungan antar 
Korelasi Latar Belakang Pendidikan Dan Minat Belajar Bahasa Arab Dengan Masa Studi Mahasiswa Prodi Pendidikan Bahasa Arab Fakultas Ilmu Tarbiyah Dan Keguruan UIN Raden Fatah Palembang

variabel yang diteliti dan jika nilai signifikansi $>0,05$, maka hipotesis kerja ditolak yang berarti tidak ada hubungan antar variabel yang diteliti.

Dari hasil analisis pada tabel di atas, didapatkan nilai sig.2 tailed latar belakang pendidikan dan masa studi adalah sebesar 0.001 yang berarti nilai tersebut lebih kecil dari nilai signifikansi 0,05. Karena nilai 0,001<0,05 maka hipotesis kerja diterima yang artinya terdapat hubungan yang signifikan antara latar belakang pendidikan dan masa studi mahasiswa prodi PBA. Kemudian berdasarkan nilai $\mathrm{r}$ hitung (Person Correlation) diketahui nilai $\mathrm{r}$ hitung untuk hubungan latar belakang pendidikan dengan masa studi adalah sebesar 0,400 atau > r tabel 0,244, maka dapat disimpulkan bahwa ada hubungan atau korelasi antara variabel latar belakang pendidikan dengan variabel masa studi. Dengan demikian hipotesis kerja diterima yang artinya terdapat hubungan yang signifikan antara latar belakang pendidikan dengan masa studi mahasiswa prodi PBA.

Selanjutnya nilai signifikansi untuk minat belajar bahasa Arab dengan masa studi mahasiswa sebesar 0,000 sebagaimana yang terdapat dalam tabel di atas pada nilai sig. 2 tailed. Karena nilai tersebut $0,000<0,05$, berarti terdapat korelasi yang signifikan antara variabel minat belajar dengan variabel masa studi. Kemudian diketahui nilai $r$ hitung untuk latar belakang pendidikan dengan masa studi adalah sebesar 0,520 yang berarti > r tabel 0,244, maka dapat disimpulkan bahwa ada hubungan atau korelasi antara variabel minat belajar dengan variabel masa studi. Jadi kesimpulannya hipotesis kerja atau hipotesis alternatid $\left(\mathrm{H}_{\mathrm{a}}\right)$ juga diterima dan hipotesis nol ditolak.

Tabel 5.

UJI KORELASI GANDA

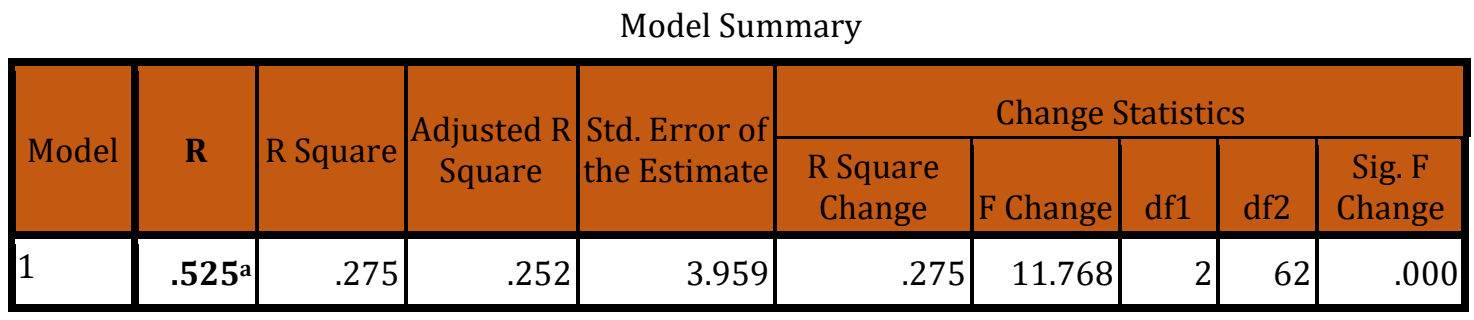

a. Predictors: (Constant), Minat_Belajar,

Pendidikan

Berdasarkan tabel diatas diketahui bahwa besar hubungan latar belakang pendidikan dan minat belajar terhadap masa studi yang dihitung dengan 
koefisien korelasi ditunjukan dengan nilai R sebesar 0,525, hal ini menunjukan pengaruh yang cukup tinggi.

Sementara itu, diperoleh nilai probabilitas (sig. F change) $=0,000$. Karena nilai sig.F canghe 0,000 $<0,05$, maka keputusannya adalah Ho ditolak dan $\mathrm{Ha}$ diterima. Artinya latar belakang pendidikan dan minat belajar berhubungan secara simultan dan signifikan terhadap masa studi.

3) Uji Prediksi

a) Uji Regresi

Uji ini dilakukan untuk melihat apakah suatu gejala atau sebuah variabel dapat dipergunakan untuk memprediksi gejala atau variabel lain.

Tabel 6.

Model Summary

\begin{tabular}{|l|r|r|r|r|}
\hline Model & \multicolumn{1}{|c|}{$\mathrm{R}$} & R Square & \multicolumn{1}{c|}{$\begin{array}{c}\text { Adjusted R } \\
\text { Square }\end{array}$} & $\begin{array}{l}\text { Std. Error of the } \\
\text { Estimate }\end{array}$ \\
\hline 1 & $.525^{\mathrm{a}}$ & .275 & .252 & 3.959 \\
\hline
\end{tabular}

a. Predictors: (Constant), Minat_Belajar, Pendidikan

Berdasarkan tabel diatas diketahui nilai R square adalah sebesar 0,275. Nilai R Square ini berasal dari pengkuadratan nilai koefisien korelasi atau "R" yaitu : 0,525 x 0,525=0,275. Besar angka koefisien R Square adalah 0,275 atau sama dengan 27,5 \%. Angka tersebut mengandung arti bahwa variabel pendidikan dan variabel minat secara simultan berpengaruh terhadap masa study sebesar $27,5 \%$.

Berdasarkan data yang dikumpulkan dan kemudian dilakukan analisis terhadap data tersebut maka jawaban terhadap hipotesa penelitian ini adalah sebagai berikut:

\section{a. Adanya Hubungan Yang Positif Dan Signifikan Antara Latar Belakang Pendidikan Dengan Masa Studi Mahasiswa Prodi PBA}

Setelah peneliti melakukan analisis korelasi dengan menggunakan program SPSS 16.0 maka didapatkan koefisien korelasi dan juga nilai signifikansi. Koefisien korelasi digunakan untuk mengetahui keeratan hubungan dan arah hubungan sedangkan nilai signifikansi digunakan untuk mengetahui apakah hubungan yang terjadi antara variabel tersebut berarti atau tidak. Untuk mengetahui keeratan hubungan maka dapat dilihat pada besarnya koefisien 
Korelasi Latar Belakang Pendidikan Dan Minat Belajar Bahasa Arab Dengan Masa Studi Mahasiswa Prodi Pendidikan Bahasa Arab Fakultas Ilmu Tarbiyah Dan Keguruan UIN Raden Fatah Palembang

korelasi dengan pedoman, yaitu jika koefisien semakin mendekati nilai 1 atau -1 maka hubungannya erat atau kuat sedangkan jika koefisien semakin mendekati angka 0 maka hubungan lemah. Untuk mengetahui arah hubungan (positif atau negatif) kita dapat melihat tanda pada nilai kooefisien korelasi yaitu positif atau negatif. Jika positif berarti terdapat hubungan yang positif artinya jika variabel bebasnya tinggi maka variabel terikatnya juga baik/tinggi dan sebaliknya jika tandanya negative maka hubungan keduanya negatif.(Prayitno, 2009:20-21)

Dari output SPSS yang telah disajikan sebelumnya didapatkan korelasi latar belakang pendidikan dengan masa studi sebesar 0,400. Merujuk kepada ring kriteria korelasi maka nilai tersebut berada pada nilai 0,25-0,5 terkategori korelasi cukup. Artinya hubungan antara latar belakang pendidikan dengan masa studi adalah terkategori cukup kuat. Sedangkan nilai signifikansi selanjutnya berdasarkan nilai sig.2 tailed dari tabel Latar belakang Pendidikan (X1) dengan Masa Study (Y) adalah sebesar 0,001 < 0,05, yang berarti terdapat korelasi/hubungan yang signifikan antara variabel latar belakang pendidikan dengan variabel masa studi. Dengan demikian hipotesis nol ditolak dan hipotesis kerja atau alternatif diterima.

Interpretasi dari analisis korelasi di atas menunjukkan bahwa masa studi mahasiswa prodi PBA memiliki hubungan yang erat dengan latar belakang pendidikan mahasiswa tersebut. Hasil penelitian ini senada dengan penelitian dari Anton Yuliawan (Jurnal Profesi Vol. 14 Nomor 1 Tahun 2016) yang berjudul Hubungan antara motivasi belajar dan latar belakang pendidikan dengan prestasi belajar mahasiswa.(Yuliawan, 2016) Salah satu jawaban dari hipotesis penelitian ini yang senada adalah bahwa ada hubungan anatara latar belakang pendidikan dengan prestasi belajar. Prestasi belajar disini peneliti menisbahkannya pada masa studi karena masa studi di perguruan tinggi banyak ditentukan oleh prestasi mahasiswa secara periodik.

b. Adanya Hubungan Yang Posistif Dan Signifikan Antara Minat Belajar Dengan Masa Studi Mahasiswa Prodi PBA

Dalam output SPSS yang telah disajikan di atas didapatkan koefisien korelasi sebesar 0,520. Berpatokan pada ring korelasi nilai tersebut terkategori memiliki hubungan yang cukup. Artinya, hubungan antara minat belajar bahasa Arab dengan masa studi terkategori cukup kuat. Sedangkan nilai signifikansi dari 
Korelasi Latar Belakang Pendidikan Dan Minat Belajar Bahasa Arab Dengan Masa Studi Mahasiswa Prodi Pendidikan Bahasa Arab Fakultas Ilmu Tarbiyah Dan Keguruan Uin Raden Fatah Palembang

korelasi sebesar 0,000 $<0,05$ maka hipotesis kerja atau hipotesis alternatif diterima yang artinya ada hubungan yang berarti antara minat belajar bahasa Arab dengan masa studi mahasiswa prodi PBA.

Nilai koefisien korelasi sebesar 0,520 yang bertandakan positif memiliki arti bahwa semakin tinggi minat belajar bahasa Arab mahasiswa maka semakin cepat ia menyelesaikan studinya. Jadi kesimpulan yang didapat dari penelitian ini adalah ada hubungan yang berarti antara minat belajar bahasa Arab dengan masa studi mahasiswa. Hubungan tersebut relatif cukup kuat karena nilai koefisien korelasi berada pada ring 0,25-0,50.

Adanya hubungan minat belajar dengan masa studi sebagaimana jawaban dari hipotesa penelitian ini senada dengan penelitian Tesis Dwi Watoyo S.M yang berjudul Hubungan Antara Lingkungan Belajar Dan Minat Belajar Dengan Prestasi Belajar Mata Pelajaran Akuntansi Siswa Kelas XI Jurusan IPS SMA Negeri I Paninggaran Kabupaten Pekalongan Tahun 2008.(Watoyo, 2008) Hasil salah satu hipotesa penelitian ini adalah bahwa ada hubungan antara minat belajar dengan prestasi belajar siswa. Prestasi dalam hal ini peneliti padankan dengan masa studi dengan alasan masa studi yang cepat biasanya ditandai dengan prestasi yang baik secara periodik.

Jadi kesimpulan yang dapat diambil dari penelitian ini adalah tinggi rendahnya atau baik buruknya minat belajar seorang mahasiswa selalu berhubungan dengan masa studi nya di perguruan tinggi. Dengan kata lain, jika minat belajar mereka rendah maka mereka akan sulit menyelesaikan studi mereka dengan tepat waktu.

c. Adanya Hubungan Yang Positif Dan Signifikan Antara Latar Belakang Pendidikan Dan Minat Belajar Mahasiswa Secara Bersama-Sama Terhadap Masa Studi Mahasiswa Prodi PBA

Untuk melihat hubungan dua variabel $\mathrm{X}$ ini secara simultan atau bersamasama terhadap variabel Y maka peneliti melakukan analisis korelasi berganda dengan hasil atau nilai $\mathrm{R}$ sebesar 0,525 yang berarti menunjukkan hubungan yang cukup kuat jika merujuk pada ring korelasi dan juga memiliki hubungan yang positif ketika kita melihat nilai korelasi di atas yeng positif.

Untuk melihat signifikansi hubungan bersama tersebut, peneliti melihat nilai probabilitas (sig. F change) $=0,000$. Karena nilai sig.F canghe $0,000<0,05$, 
Korelasi Latar Belakang Pendidikan Dan Minat Belajar Bahasa Arab Dengan Masa Studi Mahasiswa Prodi Pendidikan Bahasa Arab Fakultas Ilmu Tarbiyah Dan Keguruan UIN Raden Fatah Palembang

menunjukan adanya hubungan yang signifikan. maka keputusannya adalah Ho ditolak dan Ha diterima. Artinya latar belakang pendidikan dan minat belajar berhubungan secara simultan dan signifikan terhadap masa studi. Jadi kesimpulan terhadap penelitian ini adalah masa studi mahasiswa prodi PBA memiliki hubungan dengan latar belakang pendidikan dan minat belajar bahasa Arab secara bersama-sama.

Besarnya pengaruh kontribusi terhadap lamanya masa studi mahasiswa prodi PBA adalah dapat dilihat dari hasil regresi sederhana dan berganda dimana variabel latar belakang pendidikan memiliki pengaruh 16\%, dari variabel minat belajar 27\% dan jika secara simultan sebesar 27,5 \%. Hal ini menunjukkan bahwa latar belakang keilmuan mahasiswa yang baik akan membuat minat belajar bahasa Arab yang tinggi dan jika keduanya baik (latar belakang pendidikan dan minat belajar bahasa Arab) maka masa studi mahasiswa di perguruan tinggi secara otomatis akan singkat atau dapat selesai tepat waktu.

\section{SIMPULAN}

Ada korelasi atau hubungan yang positif antara latar belakang pendidikan dengan masa studi mahasiswa Prodi PBA. Hal ini dibutikan dengan nilai $r$ hitung (Person Correlation) diketahui nilai r hitung untuk hubungan latar belakang pendidikan (X1) dengan masa study $(Y)$ adalah sebesar 0,400 > $r$ tabel 0,244, maka dapat disimpulkan bahwa ada hubungan atau korelasi yang positif variabel latar belakang pendidikan dengan variabel masa studi. Selanjutnya berdasarkan nilai sig.2 tailed dari tabel Latar belakang Pendidikan (X1) dengan Masa Study (Y) adalah sebesar 0,001 <0,05, yang berarti terdapat korelasi/hubungan yang signifikan antara variabel latar belakang pendidikan dengan variabel masa studi. Dengan demikian jawaban terhadap hipotesa penelitian ini adalah bahwa $\mathrm{H}_{0}$ ditolak dan $\mathrm{H}_{\mathrm{a}}$ diterima. Artinya ada hubungan yang positif dan signifikan antara latar belakang pendidikan dengan masa studi.

Ada korelasi atau hubungan yang positif antara minat belajar dengan masa studi mahasiswa prodi PBA. Hal ini dibutikan dengan nilai $r$ hitung untuk hubungan minat belajar (X2) dengan masa study (Y) adalah sebesar 0,520 > r tabel 0,244, maka dapat disimpulkan bahwa ada hubungan atau korelasi antara variabel minat belajar denga variabel masa studi. Selanjutnya, hubungan antara minat belajar (X2) dengan masa study (Y) memiliki nilai sig.2 tailed sebesar $0,000<0,05$, yang berarti terdapat korelasi yang signifikan antara variabel minat belajar dengan variabel masa study. Dengan demikian jawaban terhadap hipotesa 
Korelasi Latar Belakang Pendidikan Dan Minat Belajar Bahasa Arab Dengan Masa Studi Mahasiswa Prodi Pendidikan Bahasa Arab Fakultas Ilmu Tarbiyah Dan Keguruan Uin Raden Fatah Palembang

penelitian ini adalah bahwa $\mathrm{H}_{0}$ ditolak dan $\mathrm{H}_{\mathrm{a}}$ diterima. Artinya ada hubungan yang positif dan signifikan antara minat belajar bahasa Arab dengan masa studi mahasiswa prodi PBA.

Ada korelasi atau hubungan yang positif dan signifikan antara latar belakamg pendidikan (X1) dan minat belajar bahasa Arab (X2) secara simultan (bersama-sama) terhadap masa studi mahasiswa (Y). Hal ini berdasarkan analisis korelasi berganda dengan hasil atau nilai R sebesar 0,525 yang berarti menunjukkan hubungan yang cukup kuat jika merujuk pada ring korelasi $(0,25-0,50)$ dan juga memiliki hubungan yang positif ketika kita melihat nilai korelasi di atas yang menunjukkan positif. Untuk melihat signifikansi hubungan bersama tersebut, peneliti melihat nilai probabilitas (sig. F change) $=0,000$. Karena nilai sig.F canghe $0,000<0,05$, menunjukan adanya hubungan yang signifikan. maka keputusannya adalah Ho ditolak dan Ha diterima. Artinya latar belakang pendidikan dan minat belajar berhubungan secara bersama-sama dan signifikan terhadap masa studi mahasiswa prodi PBA.

\section{DAFTAR PUSTAKA}

Permenristekdikti Nomor 44. (2015). Standar Nasinal Pendidikan Tinggi.

Prayitno, D. (2009). SPSS untuk Analisis Korelasi, Regresi dan Multivariate. Yogyakarta: Gava Media.

Safari. (2003). Evaluasi Pembelajaran. Jakarta: PT. Rineka Cipta.

Sardiman. (1994). Interaksi dan Motivasi Belajar Mengajar. Jakarta: Raja Grafindo Persada.

Slameto. (2003). Belajar dan Faktor-Faktor yang Mempengaruhi. Jakarta: Rineka Cipta.

W.S, W. (1996). Psikologi Pengajaran. Jakarta: PT. Grasindo.

Wahdanfari, A. (2014). Pengaruh Latar Belakang Pendidikan dan Pengalaman Terhadap Etos Kerja Karyawan Bank BNI Syariah Kantor Cabang Kediri. IAIN Tulung Agung.

Watoyo. (2008). Hubungan Antara Lingkungan Belajar Dan Minat Belajar Dengan Prestasi Belajar Mata Pelajaran Akuntansi Siswa Kelas XI Jurusan IPS SMA Negeri I Paninggaran Kabupaten Pekalongan.

Yuliawan, A. (2016). Hubungan Antara Motivasi Belajar dan Latar Belakang Pendidikan dengan Prestasi Belajar Mahasiswa. Profesi, 14.

Aziza, Faktor-Faktor Yang Mempengaruhi Masa Studi Mahasiswa Jurusan Administrasi Pendidikan FIP Universitas Negeri Malang, Tahun Kelulusan 2008-2010, Skripsi, Universitas Negeri Malang, 2011

Bagus, Ida, Peran Pendidikan, Pelatihan Bahasa Inggris dan Teknik Kepemanduan dalam Pengembangan MNA Wisata, Jurnal Cakrawala Pendidikan, Oktober 2014, Th, XXXIII No.3 
Korelasi Latar Belakang Pendidikan Dan Minat Belajar Bahasa Arab Dengan Masa Studi Mahasiswa Prodi Pendidikan Bahasa Arab Fakultas Ilmu Tarbiyah Dan Keguruan UIN Raden Fatah Palembang

Dyah Rahmawati, Alvi, Manajemen Pengorganisasian Program Bahasa Arab di Pare Kediri, Jurnal Arabi: Jurnal of Arabic Studies, http://Journal of Arabic Studies, 3 (1)

Hamalik, Oemar Psikologi Belajar dan Mengajar,(Bandung: Penerbit Sinar Baru Algesindo, 2012

Indriyani, Ratna , Pengaruh asal sekolah dan tempat tinggal terhadap prestasi belajar mahasiswa prodi D III Kebidanan Universitas Wiraraja Sumenep. Penelitian ini menghasilkan suatu kesimpulan bahwa ada pengaruh yang signifikan asal sekolah, tempat tinggal dan prestasi belajar mahasiswa prodi D III Kebidanan, Tesis Program Pascasarjana Universitas Sebelas Maret Surakarta, tahun 2014.

Langeveld, Ilmu Mendidik, 1976

Lesmana, Hendy, Analisis Komparatif Hasil Studi Mahasiswa latar belakang SMK dan SMA di Fakultas Ilmu Kesehatan Universitas Borineo Tarakan, Jurnal Ilmiah Ilmu-Ilmu Kesehatan Vol. 14 No 1 April 2016

Mahmud, Metode Penelitian Pendidikan, Bandung: Pustaka Setia, 2011

Martavela, Revo, Pengaruh Metode Simulasi Terhadap Minat Belajar Siswa Pada Mapel KewirausahX SMK ICB Bandung, Tesis FKIP UNPAS, 2017. http:fkip.unpas.ac.id

Mas'ud, Abdurrahman, Dari Haramain ke Nusantara; Jejak Intelektual Arsitek Pesantren, Jakarta: Prenada Media Group, 2006

Mastuhu, Dinamika Sistem Pendidikan Pesantren: Suatu Kajian Tentang Unsur dan Nilai Sistem Pendidikan Pesantren, Jakarta: INIS, 1994

Muhaimin, Wacana Pengembangan Pendidikan Islam, diterbitkan atas Kerjasama Pusat Studi Agama, Politik dan Masyarakat Surabaya dengan Pustaka Pelajar, Yogyakarta, Pustaka Pelajar, 2003

Muhibbin syah , Psikologi Pendidikan dengan Pendekatan Baru, Bandung, PT Remaja Rosdakarya, 1995

Munir, Perencanaan Sistem Pengajaran Bahasa Arab, Jakarta, Kencana, 2017

Nabilla Sitta, Anjani, Pengaruh prestasi belajar, masa studi dan keaktifan berorganisasi terhadap masa tunggu dan relevansi pekerjaan lulusan prodi pendidikan ekonomi, Skripsi Fakultas Ekonomi Universitas Negeri Yogyakarta, 2017

Nata, Abudin, Sejarah Sosial Intelektual Islam dan Institusi Pendidikannya, Jakarta: Rajawali Press, 2012

Pratiwi, Dita Ambar, dkk, Faktor-Faktor Yang Mempengaruhi Masa Studi Mahasiswa Pendidikan Teknik Bangunan Universitas Negeri Jakarta, Jurnal Pendidikan Teknik Sipil, Volume 3 Nomor 2 , Agustus 2016

Raharja, Tirta, dab La Sulo, Pengantar Pendidikan Jakarta: Depdikbud, 1994 